\title{
TLR7 Gene
}

National Cancer Institute

\section{Source}

National Cancer Institute. TLR7 Gene. NCI Thesaurus. Code C24868.

This gene plays a role in receptor signaling and in innate immune responses. 